\title{
Conflict Resolution Based on Chinese Customs in Pontianak, West Kalimantan
}

\author{
Y. Bahari \\ Department of Sociology Education, Faculty of Education and Teaching, \\ Universitas Tanjunpura Pontianak, INDONESIA. \\ yohan58.yb@gmail.com
}

\begin{abstract}
The aim of this research is to describe conflict resolution based on Chinese customs in Pontianak, West Kalimantan. This research used qualitative approach. The informants comprised of the executives, public figures and grass roots of Chinese society. The techniques of data collection were direct communication and documentary study while the instruments used interview guide and record of documents. Data processing was carried out in data reduction, data display, and conclusion drawing. The research findings are: (1) Conflict resolution based on the customs of Chinese society in Pontianak consists of Tau Kiam, and Kim Hue Ang Tiu and Ka, (2) Conflict resolution through Tau Kiam refers to the custom of asking for and giving forgiveness through mutual consensus, which is applied to cases that revolve around misunderstanding, verbal quarrel or miscommunication, (3) Conflict resolution through Kim Hue Ang Tiu and Ka refers to the custom of asking for and giving forgiveness, which are applicable to cases of slandering, disgracing someone else's good name, damaging someone else's dignity, theft, adultery, and divorce, (4) The two customs of conflict resolution are considered sacred because they were derived from Chinese religion and belief system which have been handed down from generation to generation.
\end{abstract}

\section{Keywords: conflict resolution, chinese customs}

\section{INTRODUCTION}

Harmonious life and peaceful co-existence are the ideal desired by every society. However, it is a fact that this life is never free from any conflicts, both personal and social conflicts. Like harmony, conflict is able to provide dynamics if it is managed well, or if it is transformed into lasting peace. By contrast, a conflict could be highly destructive if it is not resolved properly. The question is: How could a conflict be managed and transformed into lasting peace? One of the possibilities is through the empowerment and application of local customs. Local customs are deep-rooted local wisdom that originates from a society's culture and belief system. It has strong legitimacy if used as a medium to bring about harmonious life and peaceful co-existence. The research findings of Salahudin (2002), Satia (2003), Repalianto (2004), Bahari (2007 and 2008), Suprapto (2013), reveal that, as an alternative way, conflict resolution, which is based on a society's local custom is effective enough to resolve both intra- and interethnic conflicts. This research on conflict resolution based on Chinese customs in Pontianak, West Kalimantan is to complement and expand previous researches as well as an attempt to continually empower local customs, which serves as a kind of social asset for sustainable development
Thus far, intra and interethnic violent conflicts in West Kalimantan have been resolved through litigation and non-litigation (negotiation, mediation, conciliation, and arbitration). In fact, conflict resolution through the abovementioned two ways, often causes dissatisfaction among various parties, including the parties involved in conflicts. The dissatisfaction was caused by the fact that the resolution resulted in a winning party and a losing party. To overcome the shortcomings, an alternative conflict resolution is needed. The alternative could be obtained from the culture and belief system that exist in a customary society. Like other ethnic groups, the Chinese ethnic group also possesses customs which are capable of resolving personal and social conflicts. How the rules could be applied in conflict resolution is the question to be answered in this research.

\section{LITERATURE REVIEW}

Metharman's study (2002) on Conflict Resolution through Litigation and Non Litigation reveals that conflict resolution through a law court (litigation) contains many weaknesses [1]. The findings were which reveal that society got so fed up with conflict resolution through litigation that they attempted to seek an alternative dispute resolution (ADR). This alternative dispute resolution exists due to widespread reaction against the many weaknesses inherent in conflict resolution through litigation.

Abdurasyd (2002) states that in general there are four types of conflict resolution outside of a law court, namely: negotiation, mediation, conciliation, and arbitration [2]. While according to Nasikun (1995), there are three types of conflict resolution, namely: (1) defeating enemies through physical violence based on one's own unilateral will, (2) bargaining, in which the power to put pressure is psychological and symbolic instead of physical violence in nature, which could be carried out directly through negotiation, or indirectly through mediation, (3) turning over the matter the party who has an authority, or who is considered impartial, which could be carried out through arbitration (considering his integrity) [3]. Alternatively, it could be turned over to a law court. In line with Abdurasyd, furthermore Nasikun (1995) states that overcoming a conflict could be carried out through three alternative methods, namely: conciliation, mediation, and arbitration. The above three methods proposed are related to one another based on the conflict situation at the place of conflict [4]. 
Furthermore, all reveal that every society and region have their own way of resolving a conflict. This particular way of society is a reflection of their local wisdom, and constitutes an alternative dispute resolution (ADR), in addition to other ADRs that already exist thus far (the studies of Salahudin [5], Satia [7], Repalianto [8], Bahari [9], Haba [10], Jati [11] and Suprapto [12].

Therefore, the way we handle a conflict is a matter of custom and choice. In making any choice of conflict resolution, we are supposed to take into account the suitability of the culture and region where conflict resolution is to be carried out, so as to avoid cultural and social barriers.

\section{METHODS}

This research used a qualitative approach with ethnographic method (Spradley, 1997) [13]. The design of the research took the form of multiple side ethnographic study with analytical induction approach (Bogdan, 1992; Muhajir, 2000) [14].

The informants of this research comprised of the executives of Chinese Customs and Culture Assembly (MABT), Chinese public figures (executives of social foundation), and members of Chinese society who are knowledgeable about Pontianak Chinese culture. The techniques of data collection were direct communication technique and documentary study. The instruments of data collecting were interview guide and record of documents. All information given by the informants was recorded meticulously and thoroughly, and was confirmed with the informants in case the data lacked details.

Data processing in this research was carried out in three stages, namely: data reduction, data display, and conclusion drawing/ verification (Sugiyono, 2014) [15]. Data validity was ensured through extended observation. The researcher did extended observation by revisiting the research venue to re-interview both former and new informants. In addition, data validity was also ensured through resource, technique, and data triangulation.

\section{RESEARCH FINDINGS}

Based on the data collected and analyzed, the researcher found several forms or concepts of conflict resolution based on the customs of Chinese society in Pontianak, namely: (1) The Custom of Tau Kiam, and (2) The Custom of using Kim Hue Ang Tiu and Ka.

Tau Kiam is the custom of asking for and giving forgiveness between the parties in conflict. Usually Tau Kiam is carried out through mutual consensus. Both sides involved in the conflict would sit at the same table to talk about the cause of the dispute. This meeting was presided over by a Lau Tua. A Lau Tua is an elder who functions as a customary leader. By an elder we mean a person who is respected, feared, and who is deemed to be influential in every customary activity. Usually a Lau Tua is an elder who is capable of resolving conflicts since the judgment he made is based on justice or fairness, and impartiality.

A Lau Tua serves as a mediator who gives fair judgment so that it is always obeyed and followed up by the two sides involved in the conflict. A Lau Tua plays an important role in accommodating the conflict by serving as a mediator and arbitrator who acts as a neutral third party having an authority to mediate and give a fair judgment in conflict resolution. The status of the third party (Lau Tua) is higher the two sides involved in the conflict.

Conflict resolution through the custom of Tau Kiam is applied in conflicts that do not embarrass or disgrace the good name of an individual or a group of individuals. The nature of the conflict usually only revolves around misunderstanding or verbal quarrel. Conflict resolution through Tau Kiam can be applied not only to conflicts within Chinese society, but with non-Chinese society as well.

The custom of using Kim Hue Ang Tiu and $\mathrm{Ka}$ is concerned with conflict resolution related to slandering, disgracing someone else's good name, damaging someone else's dignity, theft, adultery, and divorce. Such custom is usually used only to resolve domestic intra-ethnic conflicts. It is seldom used to resolve inter-ethnic conflict. Kim Hue Ang Tiu is a kind of golden flower decorated with red color, and made of golden paper arranged with tiny wire. Its main function is for ancestor worship. Chinese society firmly believes that golden flower (Kim Hue) is the most special flower among all flowers. Such 'flower' is used as a realization of the highest respect to the ancestors' spirit during their worship ritual.

The sacred use of Kim Hue (golden flower) is then used as a symbol of asking for forgiveness in conflict resolution. It means that those involved in conflict earnestly seeking forgiveness as earnestly as in ancestor worship.

While Ka refers to oranges. Oranges are also used as a token of asking for forgiveness since it is believed that oranges would bring goodness to their recipients. According to Chinese customs, Ka or oranges are used as an offering to the ancestors during ritual worship, with the expectation that the ancestors would bless the worshippers back with goodness, health, wealth, and being kept safe from all harms in daily lives. Such belief is handed down from generation to generation, and becomes internalized value. If oranges are not there in a ritual worship, it is believed that all kinds of negative things would befall them.

Therefore, Ka or oranges are included in the custom of asking for forgiveness since by receiving $\mathrm{Ka}$ or oranges it is believed that the other person would receive goodness and blessing. Bad things that happened during the conflict would go away, and would be replaced by positive things.

$\mathrm{Ka}$ or oranges used in the custom of asking forgiveness should be odd in number. The number of oranges commonly used is five (5), seven (7), or nine (9). The use of odd numbers in ritual worship and asking for forgiveness signifies something alive. It means that everything originates from spirit so that worshippers are able to sense that they are conducting a dialogue with the Almighty God with pure hearts. It is all the same with the act of asking for forgiveness. The oranges given to the aggrieved party signify that the troublemaker earnestly seeks forgiveness from the aggrieved party.

Both Kim Hue Ang Tiu and Ka should be given simultaneously to the aggrieved party in the conflict. In this case, the aggrieved party is the recipient. After receiving Kim Hue Ang Tiu and $\mathrm{Ka}$, the aggrieved party 
will put the Kim Hue Ang The above the left and right door-post of the front door.

Kim Hue Ang Tiu which is put above the front door symbolizes that the aggrieved party has accepted the apology made by the wrong doer. In other words, the aggrieved party has earnestly forgiven the wrongdoer, which is symbolized by the Kim Hue Ang The above the front door. In Chinese society, the front door (Tua Meng) symbolizes the main entrance of fortune because everything enters through Tua Meng.

\section{DISCUSSION}

People in different cultures quite often have different ideologies, and such differences are important to decide the way they respond and react in a conflicting situation (Lather et al, 2010) [8]. According to Chen and Starosta (1997) [9], three aspects of culture, especially influence conflict resolution: cultural context, language differences, and thinking patterns.

Chinese society is one of the ethnicities that live in West Kalimantan province. Like other ethnicities in general, they certainly have local values. One of the local values, not much known by the general public is the value pertaining to conflict resolution. This is understandable since Chinese society were seldom involved in a physical fight, violence, adultery, cheating on one's spouse, and theft.

The rarity of such behavior causes the Chinese customs of conflict resolution to fade away with time; and therefore, not much known even by Chinese society themselves. Like conflict resolution through litigation, conflict resolution based on customary values plays an important role in maintaining social order. Conflict resolution through litigation does not really fulfil society's sense of justice, so that a conflict can happen repeatedly. Simon (t.th) explains that for conflict resolution to fulfil the sense of justice, it is necessary to dig into the root cause of the conflict. This means that local values that exist in societies are absolutely necessary in resolving conflicts so that a lasting peace is there.

Conflict resolution among Chinese society thus far was carried out under the auspices of customary foundations, and association of Chinese residents having the same clan name, as well as under the auspices of Chinese Customs and Culture Assembly (MABT). Conflict resolution is usually carried out with the help of a Lau Tua in a forum where Kim Hue Ang Tiu and Ka as well as Tau Kiam put into practice. It is a Lau Tua who serves as a custom figure and an elder. In Chinese ethnic custom, a Lau Tua is a person who is respected, feared, and who is deemed to be influential in every customary activity. A Lau Tua is an elder who is capable of resolving various conflicts, since the judgment he made is believed to fulfil the sense of justice. In other words a Lau Tua is believed to be impartial in his judgment.

There is a Lau Tua in every customer foundation, or an association of residents having the same clan name. For example, if a resident with the clan name Gouw or Tan was involved in a conflict that disgraced his good name, or damaged his dignity, he could seek the help of a Lau Tua in an association of residents with the clan name Gouw or Tan in order to resolve his conflict. If the conflict happened between residents having different clan names, they could seek the help of a Lau Tua who works at a customary foundation that represents residents with various clan names.

The process begins as soon as the parties involved in a conflict come to a customary foundation to carry out the custom of Tau Kiam. (The deliberation and exploring the opinions of the two sides involved in the conflict which was presided over by a Lau Tua from respective clans if the parties involved in the conflict were from different clans). Afterwards the Lau Tua (customary leader) listened attentively to the root causes of the conflict from the two sides. He then made an attempt to mediate between the two sides in order to judge which side was guilty, and therefore had to apologize.

The decision or judgment made by the Lau Tua must be accepted by the two sides involved in the conflict without questioning it. This is due to the fact that the status of the Lau Tua is considered higher than those involved in the conflict. In addition, the Lau Tua is considered to be an elder whose words must be obeyed, since according to Chinese customs, a Lau Tua can be likened to a judge who represents God in this world, and has had a lot of experiences in his life.

Before the parties involved in a conflict come to the stage of Tau Kiam, they would seek the assistance of their neighborhood association (RT) chief, or residents association (RW) chief, if the conflict is of small, or medium scale. However, if the neighborhood association chief, or citizens association chief was unable to mediate between the two sides, they came to a Lau Tua to carry out the custom of Tau Kiam. Whenever the case has come to the stage of Tau Kiam presided over by a Lau Tua, the judgment made by the Lau Tua must be accepted willingly. The party declared guilty should ask for forgiveness from the aggrieved party by giving him/ her Kim Hue Ang Tiu and Ka as a symbol that the apology comes from the bottom of his/ her heart, and a sincere desire to make peace.

When the party declared guilty handed Kim Hue Ang Tiu and Ka to the aggrieved party, the Lau Tua witnessed the occasion. It means that the two sides earnestly asked for and extended forgiveness to each other so that there would be no more conflict or hostility between them in the future. If the two sides meet each other intentionally or unintentionally, there should be no hard feelings between them. They are expected to have the right attitude of loving each other as taught by Buddha who is full of compassion.

Referring to the above exposition, it is obvious that conflict resolution based on customary value has positive correlation with Chinese religious teaching and customary beliefs in general. In other words, religion influences the process of conflict resolution.

\section{CONCLUSION AND RECOMMENDATION}

\section{A. Conclusion}

Based on the research findings and discussion stated above, the following conclusions could be drawn:

- Conflict resolution based on the customs of Chinese society in Pontianak consists of the 
custom of Tau Kiam, and the custom of using Kim Hue Ang Tiu and $K a$.

- Conflict resolution through the custom of Tau Kiam refers to the custom of asking for and giving forgiveness through mutual consensus preside by lau tua, which is applied to cases that revolve around misunderstanding or verbal quarrel or miscommunication.

- Conflict resolution through the custom of Kim Hue Ang Tiu and Ka refers to the custom of asking for and giving forgiveness by giving golden flower and oranges, which are applicable to cases of slandering, disgracing someone else's good name, damaging someone else's dignity, theft, adultery, and divorce.

- The two customs of conflict resolution are considered sacred because they were derived from Chinese religion and belief system which have been handed down from generation to generation.

\section{B. Recommendation}

- The study of customary values with all their underlying aspects including the study of customary values regarding conflict resolution should be carried out in order to dig into the cultural wisdom in it that existed over a period of time.

- In the future more profound scientific study should be conducted with cultural wisdom regarding ethnic Chinese conflict resolution in other places, as well as other society's ways of resolving a conflict in order to widen the horizon of scientific knowledge.

\section{REFERENCES}

[1] Abdurrasyd. 2002. Resolusi Konflik Alternatif. dalam Merthaman. Peranan Pemerintah Daerah Dalam Penyelesaian Konflik Sosial Antara Masyarakat Pendatang Dengan Masyarakat Lokal. Bandung. PPS Unpad.

[2] Bahari, Yohanes. 2007. Resolusi Konflik Berbasis Pranata Adat Etnik Dayak Kanayatn Kalimantan Barat. Dalam Jurnal Terakreditasi Wawasan . ISSN: 0852-9256. Vol. 13. No. 2. FISIP USU Medan.

[3] ---------------. 2008. Model Komunikasi Lintas Budaya Dalam Resolusi Konflik Berbasis Pranata Adat Melayu dan Madura di Kalimantan Barat. dalam Jurnal terakreditasi Ilmu Komunikasi. ISSN: 1693-3029. Vol. 6. No. 1. FISIP UPN Veteran Yogyakarta.

[4] Bogdan, Robert C. and Biklen. 1992. Introduction to Qualitative Research Methods. Alih Bahasa: Arief Furchan. Surabaya: Usaha Nasional.

[5] Chen.G.W and Starosta W.J. 1997, Chinese Conflict Management and Resolution: Overview and Implications. Intercultural Communications Studies, 7,1-16. University of Rhode Island and Howard University.

[6] Haba, John. 2008, Revitalisasi Kearifan Lokal, Studi Resolusi Konflik di Kalimantan Barat, Maluku dan Poso, cited in Abdullah et al, Agama dan Kearifan Lokal dalam Tantangan Global, Yogyakarta, Pustaka Pelajar.

[7] Jati, Wasisto Rahardjo. 2013, Kearifan Lokal Sebagai Resolusi Konflik Keagamaan, Semarang, Walisongo, Volume 21 Nomor 2.

[8] Lather. Anu Singh, Jain Shilpa and Sukla Anju Dwivedi, 2010, Cross Cultural Conflict Resolution Style: An Extensive Literature Review, Asean Journal of Management Research, on line open access publishing platform for management research, ISSN 22293795.
[9] Metharman, 2002. Peranan Pemerintah Daerah Dalam Penyelesaian Konflik Sosial Antara Masyarakat Pendatang Dengan Masyarakat Lokal. Bandung. PPS Unpad.

[10] Muhadjir, Noeng. 2000. Metodologi Penelitian Kualitatif. Yogyakarta: Rake Sarasin.

[11] Nasikun, 1995. Sistim Sosial di Indonesia. Jakarta: CV. Radjawali.

[12] Repalianto. 2004. Resolusi Konflik Yang Demokratis Dalam Perpektif Masyarakat Dayak Simpang. Yogyakarta. Tesis (S2). Program Pascasarjana. FISIP Universitas Gajah Mada.

[13] Salahudin. 2002. Setawar Sedingin. Sebuah Model Resolusi Konflik Masyarakat Adat Bengkulu. Studi Kasus penyelesaian Konflik Nelayan di Kota Bengkulu. Tesis. UGM Yogyakarta.

[14] Satia, M. R. 2003. Analisis Alternatif Kebijakan Resolusi Konflik Antara Etnis Dayak - Madura di Sampit Kalimantan Tengah. Yogyakarta. Tesisi (S2) Program Pascasarjana. FISIP Universitas Gajah Mada.

[15] Simon, Fisher. t.th, Mengelola Konflik, Ketrampilan dan Strategi Untuk Bertindak, terj. Karikasari, Jakarta, The British Council Responding to Conflict.

[16] Spradley, P. James. 1997. Metode Etnografi. Yogyakarta. PT. Tiara Wacana Yogya.

[17] Sugyono. 2014, Metode Penelitian Pendidikan, Pendekatan Kuantitatif, Kualitatif dan R \& D, Bandung, Penerbit Alfabeta.

[18] Suprapto.2013, Revitalisasi Nilai-Nilai Kearifan Lokal Bagi Upaya Resolusi Konflik, Semarang, Walisongo Vol 21, N0.1 